\title{
SOME ENVIRONMENTAL EXTERNALITIES IN REGIONAL DEVELOPMENT
}

Norton T. Dodge and John H. Cumberland

University of Maryland

\section{INTRODUCTION}

Aggregative, spaceless, traditional economics conceals the regional environmental impacts of various forms or patterns of economic growth which may not be optimal in particular regional contexts. Even much regional analysis carries over the growth bias of spaceless economics with the explicit or implicit assumption that growth maximization is an ultimate and universal regional economic development objective. Our inability to cope adequately with problems of regional development and the preservation of the quality of our environment in the face of development suggests the need for more comprehensive and appropriate concepts and methods of regional analysis.

A basic problem to date has been failure to specify clearly the objectives of regional development, but a significant literature is now emerging in this field. 1 It is evident from this literature that the effort to achieve regional economic development through crude growth acceleration is evolving into a more sophisticated concern with the dynamics of the process of regional growth, in particular, with the qualitative aspects of different alternative growth patterns. Concern for regional improvement in environmental quality and thereby in the quality of life of those living in a region is beginning to replace the narrow concern for quantitative growth alone.

Furthermore, legitimate humanitarian concern for alleviation of regional poverty, often used as a rationalization for justifying any form of industrialization, is leading to more analysis of the cost-effectiveness of various development alternatives and to the adoption of programs aimed at specific elimination of barriers to employment and productivity as an advancement over traditional trickle-down approaches.

\section{REGIONAL DEVELOPMENT OBJECTIVES}

In considering the fundamental purposes of regional economic development, most groups would agree upon several major objectives:

1. to raise per capita real incomes in the region, especially the incomes of those who are most in need;

2. to strengthen the capacity of local government to provide and improve local public services;

3. to improve the general quality of life by the wise management of the resources and environment of the region.

By testing various development proposals against these criteria it is possible to determine whether or not they would truly advance the welfare of the region or whether many of the proposals advanced in the name of progress would actually only benefit narrow special interest groups.

With regard to the first goal, improved incomes, the per capita income of the population of a region benefits over the long run from development only if significant amounts of labor and/or other inputs for the new activities are purchased on a continuing basis from within the region. Also, to achieve this goal incomes earned in the new activity should be significantly higher than the previous per capita average. In the short run, however, development-supporting activities benefit directly during the construction period regardless of the eventual effect of the new construction upon the general income level and income 
structure of the region. It is clear, therefore, that the development-supporting activities have a direct interest in fostering development as a continuing process in the region. As a result, a successful development policy tends to generate its own pressures for continuity since it results in large sales by development related activities such as construction, public utilities, real estate, banking, insurance, and legal services.

Because the construction and development supporting sectors of the regional economy can keep their sales at high levels only if development continues as a process, these sectors have a direct interest in working actively for the adoption of regional policies which encourage regional economic development on as large and continuous a scale as possible. This type of development does not necessarily lead to significant long-run improvements in regional per capita income and may aggravate local public finance problems as well as lead to serious deterioration in the quality of the local environment. However, when the development-oriented sectors of a regional economy become a significant portion of the total regional economy, then maintenance of income in the region hinges directly upon maintenance of continued growth. In such circumstances development pressures are extremely difficult to resist.

Through hard experience, it has been learned that many vigorously promoted projects for industrial, commercial and other developments do not necessarily help the residents of a region, especially if these projects pay low wages and bring in unskilled workers from outside. Unless these projects hire local people and pay high wages, they may actually lower average incomes in the area and reduce the general welfare over the long run.

Secondly, industrial commercial developments are usually justified on the basis of "broadening the local tax base," but residents of many areas have learned to their cost that new developments have also imposed new expenditure burdens on local governments for new schools, roads, water supply, sewage disposal, and welfare expenditures in excess of any new tax revenue, leaving the region worse off and with higher tax rates.

Finally, what often attracts new development into an area is not concern for local welfare but the opportunity to exploit valuable local resources. Power companies seize upon opportunities to use local water supplies for cooling purposes with resultant destruction of marine resources. Developers exploit local governments to obtain public services while polluting the water and air with their wastes and otherwise damaging the environment.

No single economic model can illuminate all of the significant aspects of a phenomenon as complex as regional economic development. However, various recent efforts have been made to introduce environmental and ecological variables into traditional economic models. ${ }^{2}$ The only rigorous method of examining all benefits and costs, including indirect and induced effects, is via a fullscale regional input-output table and social accounts as proposed by Cumberland. ${ }^{3}$ However, time, money and data did not permit this level of analysis in the present case.

\section{A REFINERY CASE STUDY}

The other author, Norton T. Dodge, recently participated in a regional development study ${ }^{4}$ to assess the benefits and costs of establishing a free trade zone and oil refinery in a rural, tidewater Maryland region - a region possessing other significant growth potentials based upon its unusually high quality recreational and environmental resources and its close proximity to the growing East Coast megalopolis.

Early in the summer of 1968, a Washington, D.C., petroleum distributing 
firm proposed to make substantial additions to its facilities at Piney Point on the Lower Potomac River in St. Mary's County, Maryland, some sixty air miles south and east of Washington, D.C. The proposal included establishment of an oil refinery (topping plant) ${ }^{5}$, significant additions to the tank farm, and an additional loading and unloading pier. Heated local debate concerning the desirability of the project led the Board of County Commissioners to appoint a committee to study and report on the probable impact of the proposed facility on the total economy of the County. This paper draws on the Committee's work and attempts to push the analysis further.

Our aim is to estimate the effects of externalities in two important respects:

A. Estimates of "threshold levels" at which external diseconomies (retardation of growth in other sectors) from oil refining could negate economic benefits (income and tax revenues) from the oil refinery complex.

B. Estimates of the extent to which environmental externalities from petroleum refining and related activities could be expected to impair other development options.

In evaluating the impact of the refinery it is assumed that the fundamental goal of economic development is to improve the quality of life of those living in St. Mary's County both at present and in the future. It is recognized that more jobs, more income, and more government services are wanted, but not at the cost of resource mismanagement. It is also recognized that economic development would probably involve some deterioration in environmental quality for the general public in return for benefits to a few. Thus a major question was the extent to which the County was willing to trade off deterioration in environmental quality for increased economic development.

The decision of the County Commissioners to disapprove the project was made with reference to the impact of costs and benefits on their own County and its citizens. Our analysis is concerned, therefore, with costs and benefits to St. Mary's County alone. Since certain tax benefits and income effects would be concentrated in the County while some of the burden of costs would spill over into adjoining Charles County and Virginia, our analysis is only a partial analysis. It reflects, however, the faults of the decision making mechanism of our political and economic system.

\section{BENEFITS}

Although potential benefits are more immediately apparent and measurable than many of the potential costs, doubt exists regarding some of the claimed benefits because of the indefinite and uncertain plans for the processes and facilities to be employed in the proposed Piney Point refinery complex.

Taxes: Based upon engineering estimates of the required capital investment and current tax rates, yearly revenues to the County government from the refinery would average approximately $\$ 400,000$ over the ten-year period following completion of the refinery. 6

However, if the proposed refinery's capital requirements were in line with those for the comparable components of the complete refinery proposed for the Machiasport Foreign Trade Zone in Maine, the addition to County revenues would be $\$ 300,000$ per year. For perspective, these possible revenues would be equivalent to those which would be yielded by a tax increase averaging $\$ 30-40$ per family in the County.

Earnings: According to engineering estimates, the refinery would employ 85 persons. It is estimated that some 65 of these, largely the less skilled, would be County residents. If the new pier were not built, or if the same crew served both piers, additional employment of County residents by the project might number only 40. If salaries averaged as much as $\$ 10,000$ a year, ${ }^{7}$ income to County residents employed by the refinery might total $\$ 400,000$ to $\$ 640,000$ depending on 
the number actually employed.

However, should all County residents employed by the refinery be replaced in their former jobs by persons coming from outside the County, the gain in incomes to County residents would be limited to the increased earnings of these residents in their refinery jobs over their earnings in their previous jobs. In practice, however, some of the vacancies created down the line would likely be filled by County residents. If three quarters were so filled total payrolls to existing County residents might be increased by $\$ 300,000$ to $\$ 400,000.8$ Since the owners of the project do not live in the County, no incomes other than the salaries and wages discussed would be increased.

The maximum combined monetary benefits to citizens of the County from taxes and increased payrolls from the refinery might possibly be as high as $\$ 1,000,000$ but benefits of this magnitude are far from certain. In the opinion of the authors benefits in the range of $\$ 600,000$ to $\$ 800,000$ are more likely. For perspective, such benefits amount to about one-half of one percent of the present personal income of the County, a percentage which will decline further in significance as County income increases.

As will be seen in the following discussion, these possible gains are trivial when compared to the potential dangers that an oil refinery and related developments would present to the County economy now and in the future.

\section{THRESHOLDS OF ACCEPTABLE COSTS}

How would the present uses of the Lower Potomac area be affected by the development of a refinery complex at Piney Point? Can we express probably damage to these uses in dollars and cents? Given the present state of the art, these questions cannot be answered with a high degree of precision. However, rough estimates can be made. Since costs are very difficult to measure precisely, particularly those which involve aesthetic values or whose burden is widely spread, we shall temporarily sidestep this issue and determine first what order of adverse effects on various sectors of the County economy would serve to wipe out the benefits expected from a refinery complex.

Our approach is relatively uncomplicated and straightforward Estimates of St. Mary's County's personal income by major sources and earnings from broad economic sectors in 1959 and 1966 were obtained from the Regional Economics Division, Office of Business Economics, Department of Commerce. Straight line projections to 1971 , the earliest year in which the refinery could be put into operation, and to 1980 , ten years later, were made component by component on the basis of the 1959 to 1966 growth. Projections of some of the components which showed the most rapid growth such as military income, property income, and federal civilian income were reduced to amounts which better fitted the projection of total personal income. Thus, our estimates of growth are conservative ones.

From these projections, estimates of expected 1971 and 1980 income generated by those sectors most likely to be adversely affected by the refinery were made. Some adjustments, particularly for income from the seafood industry, were made because of evident underreporting in the Department of Commerce data.

Comparison of these income projections with the estimated total benefits expected from the refinery yielded the computations in Table $I$ of the retardation in growth rates in each sector which would offset benefits from the refinery. Thus the figures in Table I are estimates of threshold levels at which costs from retardation in growth rates of other activities caused by external diseconomies from the refinery would begin to exceed benefits from the refinery. Each of these sectors is discussed below.

Seafood: The local industry most likely to suffer from water pollution is 
the seafood industry. The importance to St. Mary's County of the $\$ 3,000,000$ industry is substantial both from the standpoint of income and employment. Repeated or major oil spills in the Lower Potomac would unquestionably threaten the health and growth of this industry. Any possible benefits to the County from the proposed refinery could be entirely wiped out if water pollution or spills caused as much as one-quarter reduction in income from the seafood industry alone. Given normal growth of the seafood industry to 1980 , even damage amounting to only 12-15 percent would cancel out any benefits.

Tourism and Recreation: The development of a refinery would exhaust that part of the County's store of recreational resources represented by the Piney Point area and could lead to more widespread damage to tourism and recreation as well as to second-home and retirement living. These all have a great potential in the County because of its proximity to the rapidly expanding Washington-Baltimore metropolitan area, and they can be expected to grow faster than the rest of the economy.

Tourism would be adversely affected by a refinery complex through damage to the aesthetic attractiveness of Piney Point and the surrounding area as well as from pollution and oil spills which would damage fishing, boating, and marine activities. Also adversely affected by spills would be waterfowl, including the thousands of birds that travel the Atlantic flyway and winter in the area. The development of the historic site of St. Mary's City, six air miles away, and the related growth in tourism would be threatened as would be, also, the development of adjoining St. Mary's College.

By the date the refinery could be in operation, income from tourism and recreation oriented activities could be expected to be $\$ 6$ million (5 percent of total County earnings in 1971). A 13 percent retardation in the growth of tourist and recreation income would, therefore, wipe out any gains to the County from the refinery.

More important would be the effect of the refinery on the future growth of this industry. Under normal circumstances, the importance of tourism and recreation to St. Mary's County can be expected to approach the average level for Southern Maryland (11 percent of total earnings).10 Such a development would mean that income from tourism and recreational activities in the County would reach $\$ 20$ million in 1980. If the presence of the refinery reduced the growth of this type of income by only 4 percent, the gain to the County from the refinery complex would be wiped out. See Table 1 .

The threshold values which we have determined indicate that even a relatively small cutback in the growth of personal income or total earnings would cancel out any benefits from the refinery. If we focus on the specific reasons for such a cutback, we find that potential damage to the seafood industry or to tourism and

Table 1

PERCENTAGE REDUCTION IN INCOME OF VARIOUS

SECTORS IN THE COUNTY ECONOMY WHICH WOULD EXCEED

ESTIMATED BENEFITS FROM THE OIL REFINERY

Activity 1966

1971

1980

Seafood

$25 \%$

18

0.9

0.7
$20 \%$

12

0.7

0.5
$12-15 \%$

4

0.4

0.3

SOURCE: Calculated from Report..., p. 10 and the figures given in the text above. 
recreation is the main problem. A relatively small cutback in any one of these activities would wipe out the expected benefits. In practice, of course, damage to one is likely to involve damage to another. Therefore, quite small damage to each activity could in combination offset any expected benefits. For example, in 1980 a 10 percent cutback in income from the seafood industry plus a 2 percent cutback in income from tourism and recreation would more than offset any expected gains from the refinery.

Another way by which the benefits anticipated from a refinery complex might be offset is through the need for increased government expenditures on public services such as schools and sewage systems and the increased wear and tear on existing public services such as roads which would result.11 Although we do not place a figure on anticipated increases in government expenditures which would offset part of. the additions to tax revenues and incomes in the County, we can be certain that they would serve to offset in some degree these benefits, the extent of the offset being dependent upon the precise nature and extent of the expansion of the refinery and related industries.

\section{POTENTIAL COŚTS}

Having examined the extent of the damage to various sectors of the St. Mary's economy which would offset any expected gains from the refinery complex, we must now inquire into the probabilities that damage of these magnitudes will occur. At present this is a question which is impossible to answer with any precision. Nevertheless, any policy decision for or against the establishment of a refinery complex unavoidably must be based upon implicit assumptions regarding the probability of damage.

Water Pollution: The major threat to the area from the refinery complex is from water pollution. Pollution from a refinery has several sources:

1) Thermal pollution may cause adverse effects on seafood and other marine life if river water is used for colling without proper standards and precautions.

2) Pollution by waste discharge from a refinery is another major problem. It can be reduced and possibly largely eliminated if the latest technology is employed; this has seldom been done. Expansion from a topping plant to a full fledged refinery involving catalytic cracking would, of course, greatly increase the waste treatment and waste disposal problem and increase the potential danger to the area. 12

3) Finally, as recent events off the Santa Barbara coast have demonstrated, pollution from accidents cannot be controlled with any assurance. Frequent small spills or leaks would have a cumulative adverse effect on a limited area around Piney Point. One major crude oil spill, however, could affect many miles of river and ruin an oyster harvest, taint the flavor of fish, kill wintering and migrating water fow1, and do damage to hundreds of boats and miles of shoreline and beaches. Repeated major spills could have severe and lasting adverse effects on the seafood industry of the entire Lower Potomac as well as on the propagation of the seed oysters in nearby St. Mary's River which are used in other areas of Chesapeake Bay.

Development of the proposed refinery would increase the danger of spills substantially in two respects: 1) the 100,000 barrels of petroleum brought in on an average each day would be crude oil, which is much more toxic and damaging to marine life than fuel oil; 2) the volume of shipments of all products would be increased substantially. According to the company, an average of 40,00050,000 barrels of petroleum products is shipped in and out of their present storage facilities every day. This might increase to over 100,000 barrels a day in a few years with the planned expansion of these facilities. With the addition of the proposed topping plant, the volume of shipments would increase to an average of 200,000 barrels a day, plus the amounts of gasoline and asphalt currently handled. Expansion to a 200,000 barrel a day full refinery, which an engineering consultant considers a real prospect, 13 would double again the volume of both crude oil and total petroleum products handled. Thus, exposure to damage from spills 
would be increased some fivefold with the addition of a topping plant and tenfold with a full refinery.

Safeguards for the handling of oil are far from foolproof at the present time and are only effective under favorable weather conditions. It appears, therefore, that barring any significant improvement in technology the danger of oil spills in the area would increase in proportion with increases in the volume of crude and other petroleum products handled.

If we limit our concern for the moment to estimating damage from oil spills, we should very much like to provide answers to questions such as what is the probability of an oil spill occuring in the next year which would cause X dollars of damage? In the next five years? In the next ten years? We would like similar answers for spills causing $\mathrm{Y}$ and $\mathrm{Z}$ dollars of damage. Unfortunately present statistical data on oil spills are neither sufficient nor of a nature to provide definite answers to such questions. Nevertheless, any time we, as economists, or the County Commissioners, as the responsible decision makers, say, "We believe the chance of serious damage to the seafood industry from oil spills is great," or ".... is small," a table such as follows is filled in implicity in our minds if not explicitly on paper. See Table 2 .

Even such a table is far from precise since it does not quantify "small," "moderate," or "major," for degrees of severity or "extremely low," "very low," or "low," etc., for probabilities. Despite this unavoidable lack of precision at the present time we deem it desirable that advisors or decision makers be forced to make explicit the implicit bases of their advice or decisions. Then these explicit assumptions can be discussed openly and confronted with whatever

Table 2

ESTIMATED PROBABILITY OF OIL SPILLS AT OR RELATED TO THE REFINERY COMPLEX

Severity of Spil1

Time Period

\begin{tabular}{llccc} 
& $\begin{array}{c}\text { 1 year } \\
\text { Period }\end{array}$ & $\begin{array}{c}5 \text { year } \\
\text { Period }\end{array}$ & $\begin{array}{c}10 \text { year } \\
\text { Period }\end{array}$ & $\begin{array}{c}\text { 20 year } \\
\text { Period }\end{array}$ \\
\hline $\begin{array}{c}\text { Small in size } \\
\text { and damage }\end{array}$ & moderate & high & very high & $\begin{array}{c}\text { extremely } \\
\text { high }\end{array}$ \\
$\begin{array}{c}\text { Moderate in size } \\
\text { and damage }\end{array}$ & low & moderate & high & very high \\
$\begin{array}{c}\text { Major in size } \\
\text { and damage }\end{array}$ & very low & low & moderate & high \\
$\begin{array}{c}\text { Catastrophic in } \\
\text { character }\end{array}$ & extremely & very low & low & moderate \\
\hline
\end{tabular}

relevant data may be available. Clearly a catastrophe such as occurred in the Santa Barbara Channel might not be avoided by this process, but it would not be stumbled into without some attempt, even though inadequate, to weigh the probably costs against the benefits of such an action.

Since damage to the environment by a refinery complex comes from a number of factors in addition to oil spills, the other forms of damage such as scenic, noise, sme11, etc., should be integrated into any estimate of expected damage. Any evaluation of such environmental costs must recognize that these costs are 
TABLE 3

PROBABILITY OF DAMAGE FROM THE REFINERY COMPLEX

TO ACTIVITIES IN THE SURROUNDING AREA

\begin{tabular}{|c|c|c|c|c|c|}
\hline \multirow{3}{*}{ Activity } & \multicolumn{5}{|c|}{ Extent of Damage to Activity } \\
\hline & \multicolumn{2}{|c|}{$\begin{array}{l}\text { Probability of } \\
\text { "Some" damage }\end{array}$} & $\begin{array}{l}\text { Probability of } \\
\text { "Considerable" } \\
\text { Damage }\end{array}$ & \multicolumn{2}{|c|}{$\begin{array}{l}\text { Probability of } \\
\text { "Great" damage }\end{array}$} \\
\hline & $\begin{array}{l}\text { Within } \\
\text { lst yr. }\end{array}$ & $\begin{array}{l}\text { Within } \\
10 \text { yrs. }\end{array}$ & $\begin{array}{l}\text { Within Within } \\
\text { lst yr. } 10 \text { yrs. }\end{array}$ & $\begin{array}{l}\text { Within } \\
\text { 1st yr. }\end{array}$ & $\begin{array}{l}\text { Within } \\
10 \text { yrs. }\end{array}$ \\
\hline Oysters and Seafood & moderate & high & moderate high & low & moderate \\
\hline Waterfow1 & moderate & high & moderate & low & moderate \\
\hline Tourism & high & high & moderate & low & moderate \\
\hline Recreation & high & high & moderate & low & moderate \\
\hline $\begin{array}{l}\text { Existing land use } \\
\text { (primarily homes in } \\
\text { immediate area) }{ }^{1}\end{array}$ & high & high & high & high & high \\
\hline $\begin{array}{l}\text { Existing } 1 \text { and use } \\
\text { (in broader area) }{ }^{2}\end{array}$ & moderate & high & moderate & low & low \\
\hline $\begin{array}{l}\text { Aesthetics } \\
\text { (in immediate area) }^{1}\end{array}$ & high & high & moderate high & moderate & moderate \\
\hline $\begin{array}{l}\text { Aes thetics } \\
\text { (in broader area) }{ }^{2}\end{array}$ & moderate & high & moderate & low & low \\
\hline
\end{tabular}

$1_{\text {Within a }}$ one mile radius of the perimeter of the refinery complex

2 Within a five mile radius of the perimeter of the refinery complex 
very real even if quite elusive.

They will be reflected in dollars and cents in this instance primarily insofar as they retard growth in tourism and recreation. They will also be reflected in a decline in nearby property values. While some nearby property will likely increase in value because of its potential industrial or commercial use, the value of residential property for residential use near a refinery will decline with certainty. As an illustration, the value of an historic manor near the existing tank farm was depressed an estimated forty percent by its proximity to the storage facilities. After several transfers, the property was ultimately acquired by the petroleum distributing company and now provides the basis for their refinery and other expansion plans. What has happened to residential real estate values in the vicinity of the Yorktown, Virginia, refinery is also instructive. Residential properties caught between the refinery and the river or in close proximity on either side have suffered substantial reductions in value and have since failed to appreciate as much as comparable properties elsewhere. 14

Again data for precise estimation of environmental costs are lacking, but experience at other refinery site and expert testimony can serve to provide a fairly reliable assessment of probably expected damage in broad terms.

Table 3, like Table 2, forces us to arrive at explicit even if imprecise conclusions about the probably damage to various aspects of the environment from a refinery complex. By requiring some thought about short term (one year) versus long term (ten year) effects it compels one to consider delayed and cumulative environmental effects.

\section{SLMMARY AND CONCLUSION}

In evaluating the proposal to construct a petroleum refinery in one of the less developed regions of Maryland, conventional regional development concepts would have suggested significant economic benefits in the traditional mode.

However, application of more general analytic techniques accounting for environmental externalities revealed the existence of probable indirect effects and costs which would negate or exceed the benefits expected from construction of the petroleum refinery.

Traditional national development models and the regional development models which have been uncritically adopted from them are biassed toward assumptions that all economic activities tend to grow pari passu. It is explicitly or implicitly assumed that regional supply functions are infinitely elastic.

We have attempted to show that more advanced models of regional development must give appropriate weight to the elasticity of supply of environmental factors for regional growth. Particularly, if achieveing or maintaining high quality of air, water, and other environmental quality factors is an important regional objective, the supply function for regional development may be inelastic.

Under these circumstances, decisions to pursue some pattern of regional economic development may imply limitations upon other opportunities for future development. This is a factor which has been neglected in regional and national economic analysis. 
FOOTNOTES

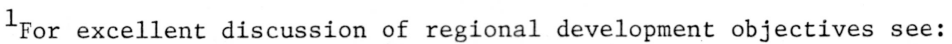
Joseph L. Fisher, "Concepts in Regional Economic Development," Papers and Proceedings of the Regional Science Association I (1955); Roland Artle, "Public Policy and the Space Economy of the City," in Lowdon Wingo, Jr., ed., Cities and Space, The Future Use of Urban Land (Baltimore: Johns Hopkins University Press for Resources for the Future, Inc., 1963); Charles L. Leven, "Establishing Goals for Regional Economic Development," Journal of the American Irstitute of Planners 30, No. 2 (May 1964): 100-110; Thomas A. Reiner, "SubNational and National Planning: Decision Criteria," and references therein, Papers and Proceedings of the Regional Science Association 14 (1.965); Wilbur R. Thompson, A Preface to Urban Economics (Baltimore: Johns Hopkins University Press, for Resources for the Future, Inc., 1965), p. 1.

${ }^{2}$ John H. Cumberland, "A Regional Interindustry Model for Analysis of Development Objective," Papers at the Regional Science Association, 1966, pp. 65-94; Walter Isard, et al, Ecological-Economic Analysis for Regional Development, Harvard Graduate School of Design, report to ESSA and EDA, December 1969, shows how some types of growth may retard others.

${ }^{3}$ Cumberland, op. cit.

${ }^{4}$ Commissioners Study Committee, Report to the Board of County Commissioners, St. Mary's County, on the Proposed Steuart Facility at Piney Point, Maryland, (mimeographed), October 1968,105 pp. plus appendices, hereafter referred to as Report... .

${ }^{5} \mathrm{~A}$ topping plant is engaged in the distillation of crude petroleum, but not in the catalytic cracking of petroleum products.

${ }^{6}$ Under existing tax laws, exempting personal property such as machinery and equipment from taxation, a very small tax would be paid to the County by the refinery were it not that the sponsors of the refinery proposal agreed to waive the exemption.

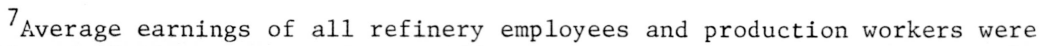
$\$ 8,400$ and $\$ 7,900$ respectively in 1966 according to the 1968 Statistical Abstract of the United States.

$8_{\text {No }}$ consideration is given here to the possible multiplier effects of the increased income received by County residents and newcomers. Such certainly exist but are limited in extent due to the large leakages out of a small County near urban centers such as Washington and Baltimore. More importantly, since we shall be concerned with costs which equal and cancel out benefits, we can omit the multiplier effects of benefits if we do so with costs as well. A discrepancy will exist, however, in that income received by newcomers is not counted as a benefit to County residents, although this income would, of course, have multiplier effects beneficial to County residents' income.

${ }^{9}$ See Report..., p. 12.

$10_{\text {Report ..., p. } 64 .}$

${ }^{11}$ In the case of a topping plant alone, costs to the local government would be small. However, if substantial other industries employing more workers and not agreeing to waive their tax exemptions were attracted to the area, once a refinery had opened the door to heavy industry, the burden could be much greater. Unfortunately, our measures of costs and benefits of the project are largely 
FOOTNOTES---Continued

static and limited to the refinery proposal. If more information, knowledge and time were available, a more dynamic treatment of cost and benefits would be attempted.

12 The addition of satellite petrochemical plants and other heavy industry would, of course, increase the volume of industrial waste discharge in the Piney Point area and increase the possibility of pollution. It is not certain that with present government enforcement personnel, maintenance of present water standards could be guaranteed in the area.

13 See Report . . .., Appendix 1.

${ }^{14}$ Ibid., pp. 55-61. 